\title{
HYDROLYSIS OF CASEIN AND $\beta$-LACTOGLOBULIN BY IMMOBILIZED PAPAIN AFTER PRE-TREATMENT WITH IMMOBILIZED TRYPSIN
}

\author{
T.B. Pessato ${ }^{a}$ and O.L. TAVAnO ${ }^{\text {b* }}$ \\ ${ }^{a}$ Departament of Nutrition, Triângulo Mineiro Federal University, Rua Getulio Guaritá, 159, CEP 38025 360, \\ Uberaba, Minas Gerais. Brazil \\ ${ }^{\mathrm{b}}$ Faculty of Nutrition, Federal University of Alfenas, Rua Gabriel Monteiro da Silva, 700, Prédio H, sala 106D, \\ CEP 37130 000, Alfenas, Minas Gerais. Brazil
}

(Received: 12 May 2014; accepted: 28 August 2014)

Protein hydrolysis using immobilized proteases may present problems, which are mainly caused by the diffusion of macromolecular substrate. Pre-hydrolysed substrate could be a viable alternative in this process. The aim of this work was to test the casein and $\beta$-lactoglobulin hydrolysis using immobilized papain on glyoxyl-agarose, following substrate pre-treatment with immobilized trypsin. Although immobilized papain showed difficulties to degrade the milk proteins, after $10 \mathrm{~min}$ of trypsin pre-hydrolysis, the immobilized papain was able to achieve the maximum degree of hydrolysis in shorter time. For pre-hydrolysate casein, the immobilized papain reached $98.9 \%$ at $60 \mathrm{~min}$ total reaction (including the $10 \mathrm{~min}$ pre-digestion). As for $\beta$-lactoglobulin, immobilized papain was capable of achieving maximum levels after just 60 min of reaction, where the free enzyme only achieved $60 \%$ of its maximum. Pre-hydrolysis with trypsin appears to have worked well as a pre-treatment method to increase the proteolytic action of immobilized papain.

Keywords: casein, $\beta$-lactoglobulin, papain, trypsin, enzyme immobilization, glyoxyl-agarose

Protein hydrolysates containing specific short-chain peptides have been highly desired in clinical diets or specific formulations (CLEMENTE, 2000). Enzymatic protein hydrolysis could release peptides, which provide health benefits beyond the basic nutritional effects, depending on protein amino acid composition and sequence. Milk proteins are well documented as "sources" of bioactive peptides (Отте et al., 2007) that can have beneficial health effects on cardiovascular, digestive, immune, and nervous systems (Silva \& Malcata, 2005). On the other hand, cow milk proteins constitute one of the most important food allergens in young children's diet (SAMPSON, 1999). Caseins and $\beta$-lactoglobulin are considered major causes of allergic response to cow milk (El-AgAmy, 2007; Dupont et al., 2010). Since $\beta$-lactoglobulin is a major whey protein component in cow, buffalo, sheep, goat, mare, and donkey milk and it is absent in human milk, this protein could be resistant to infant gastric digestion (KLEBER et al., 2004). Therefore, cow milk hydrolysate proteins are also considered viable alternatives for infant formulas.

Although the appropriate choice of the enzymatic processing can provide specific and preserved peptides, enzymatic hydrolysis may present certain difficulties. For example, food samples may exhibit variable composition, being a rich culture medium. Hydrolysis at mild temperature conditions may provide microbiological growth, which calls for the use of higher processing temperatures. In this case, the thermal stability of the immobilized enzymes could

* To whom correspondence should be addressed.

Phone/Fax: +55-34-3299-1110; e-mail: tavanool@yahoo.com.br

0139-3006/\$20.00 @ 2015 Akadémiai Kiadó, Budapest 
be an attractive alternative. Multipoint enzyme immobilization can enhance their stability via the prevention of subunit dissociation and, moreover, the unfolding rate of protein chains, promoting "rigidification" of three-dimensional enzyme structures (UlbRICH-HofMANN et al., 1999; MATEO et al., 2006). Different supports can be used. Glyoxyl-agarose support containing a large number of stable aldehyde groups can immobilize proteins via, at least, a two-point reaction involving the region/s of the protein surface with high densities of amino groups (MATEO et al., 2006). In addition to stabilization, the use of immobilized enzymes renders inactivation of the enzyme at the end of the process unnecessary, since the catalyst can be easily removed from the reaction medium. This avoids the usual thermal inactivation as the final step and its consequent protein/peptide aggregation, and could be especially important in limited hydrolysis, making it possible to obtain greater control of the desired hydrolysis degree (Yust et al., 2010).

Gastrointestinal digestion is the natural route to produce bioactive peptides through food protein hydrolysis, but other non-digestive enzymes have been studied for the release of different fragments with a wide range of actions (Clemente, 2000; TAVAnO, 2013). Papain, a member of the cysteine protease family, is an endopeptidase extracted from the latex of Carica papaya, which is widely studied for food process applications. Papain is a relatively heat stable and simple protein, presenting a single and small chain (YеOM et al., 1999), which makes it interesting for immobilization purposes. The aim of this work was to test hydrolytic response of casein and $\beta$-lactoglobulin using papain immobilized onto glyoxyl-agarose, considering trypsin pre-digestion.

\section{Materials and methods}

\subsection{Reagents}

Agarose 4BCL was from GE HealthCare Life Science, papain from papaya latex (P-4762), trypsin from porcine pancreas (T-0303, type IX-S), casein (C-7078) and $\beta$-lactoglobulin (L3908) from bovine milk were from Sigma Chemical Co.

\subsection{Methods}

All experiments were performed at least in triplicate and the results are presented as their mean values. Experimental error never exceeded 5\%.

1.2.1. Enzyme immobilization. Glyoxyl-agarose support was prepared with the highest activation degree, as previously described by GuISÁN (1988). To $73 \mathrm{~g}$ of this agarose $50 \mathrm{ml}$ of distilled water, $34 \mathrm{ml}$ of $1.7 \mathrm{~N} \mathrm{NaOH}$ containing $0.95 \mathrm{~g}$ of sodium borohydride, and $6.7 \mathrm{ml}$ of glycidol (2,3-epoxi-propanol) were added. After $18 \mathrm{~h}$ of agitation, the support was washed with abundant distilled water and vacuum filtered. Glyoxyl-agarose was prepared with 825 $\mathrm{ml}$ of water and $175 \mathrm{ml}$ of $0.1 \mathrm{M}$ sodium periodate. The consumption of periodate (directly related to the aldehyde residue generated in the support) was checked by adding $0.2 \mathrm{ml}$ of the supernatant of the oxidizing suspension to a mixture of $1.5 \mathrm{ml}$ of $10 \mathrm{~g} / 100 \mathrm{ml} \mathrm{KI}$ and $1.5 \mathrm{ml}$ of saturated sodium bicarbonate. The absorption was read at $419 \mathrm{~nm}$, considering the initial sodium periodate solution as $100 \%$ ( $0 \%$ aldehyde production). Enzyme derivatives were prepared using this highly activated glyoxyl-agarose support (71 micromoles of glyoxyl groups/g). This procedure enables the enzymes to interact with support through multiple 
points. Increasing protein:support ratios were tested for each enzyme (trypsin: $0.2-3.0 \mathrm{mg} \mathrm{g}^{-1}$ support; papain: $0.5-10.0 \mathrm{mg} \mathrm{g}^{-1}$ support), with the highest possible protein loads being achieved using $2.0 \mathrm{mg} \mathrm{g}^{-1}$ for trypsin and $8.0 \mathrm{mg} \mathrm{g}^{-1}$ support for papain. The prepared support was suspended in an enzyme solution ( $10 \mathrm{~g}$ gel: $100 \mathrm{ml}$ enzyme solutions in $100 \mathrm{mM}$ sodium bicarbonate buffer $\mathrm{pH} 10.2$ ) and gently stirred at $5{ }^{\circ} \mathrm{C}$ for $24 \mathrm{~h}$. Prepared biocatalysts (derivatives) were reduced by adding sodium borohydride to reach $1 \mathrm{mg} \mathrm{ml}^{-1}$ (MATEO et al., 2006).

1.2.2. Protein determination. Protein concentration was determined by the BRADFORD (1976) method using bovine serum albumin (BSA) as a standard.

1.2.3. Enzymatic activity. Trypsin activities were measured using BAPNA (benzoyl-DLarginine- $p$-nitroanilide) as substrate ( $40 \mathrm{mg}$ of BAPNA in $1.0 \mathrm{ml}$ dimethyl sulfoxide in a total volume of $100 \mathrm{ml}$ using $0.02 \mathrm{M}$ Tris buffer, $\mathrm{pH} 8.2$, as described by KAKADE and co-workers (1974); and papain activities were also measured using BAPNA in $0.02 \mathrm{M}$ Tris buffer containing $1 \mathrm{mM}$ EDTA and $5 \mathrm{mM}$ cysteine, $\mathrm{pH} 7.0$, as described by Yеом and co-workers (1999) with some modifications. Briefly, to $500 \mu \mathrm{l}$ of enzyme (or $0.1 \mathrm{~g}$ of derivatives) $2.0 \mathrm{ml}$ of substrate solution was added and the reaction mixture was incubated at $50{ }^{\circ} \mathrm{C}$ for $10 \mathrm{~min}$. The reaction was stopped by adding $250 \mu 1$ of $30 \%$ acetic acid and the Abs was measured at $410 \mathrm{~nm}$. One unit of activity is arbitrarily defined as an increase of $0.01 \mathrm{Abs} / \mathrm{min}$.

1.2.4. Influence of temperature and $p H$ on the activities of immobilized enzymes. The effect of $\mathrm{pH}$ on immobilized enzymes was determined in $0.02 \mathrm{M}$ TRIS-HCl buffer (containing $1 \mathrm{mM}$ EDTA and $5 \mathrm{mM}$ cysteine when papain was used) for $\mathrm{pH}$ 6.0-8.0 range, and $0.01 \mathrm{M}$ glycine- $\mathrm{NaOH}$ buffer for $\mathrm{pH} 9.0$, at $50{ }^{\circ} \mathrm{C}$. The effect of temperature on the activity of enzymes was determined from $37^{\circ} \mathrm{C}$ to $80^{\circ} \mathrm{C}$, at $\mathrm{pH}$ 7.0.

1.2.5. Casein and $\beta$-lactoglobulin hydrolysis. Proteins were dissolved in $0.02 \mathrm{M}$ TRIS$\mathrm{HCl}$ buffer, $\mathrm{pH} 7.0$, at a concentration of $2.4 \mathrm{~g} / 100 \mathrm{ml}$ and $0.6 \mathrm{~g} / 100 \mathrm{ml}$, in order to simulate the same concentration of these proteins in normal cow milk. Digestions were carried out using 1:100 enzyme to protein ratio, for $120 \mathrm{~min}$, at $60^{\circ} \mathrm{C}$. At different times aliquots of the supernatant were withdrawn. The reaction was stopped by boiling for $5 \mathrm{~min}$. The extent of hydrolysis was measured by the increase of free amino groups, using OPA (o-phthaldialdehyde) reagent as describe by СнURCH and co-workers (1983) with some modifications. Briefly, to 10 to $100 \mu \mathrm{l}$ of hydrolysate $1.0 \mathrm{ml}$ of OPA reagent was added, the solution was mixed briefly, and the absorbance at $340 \mathrm{~nm}$ was measured after exactly 2 min. A standard curve of L-leucine was constructed. The ratio used to the calculation of the percent hydrolysis $(\% \mathrm{H})$ was:

$$
\% \mathrm{H}=(\mathrm{AAs}-\mathrm{AAba}) / \mathrm{AAtm}
$$

where: AAs=moles of amino acids determined in the sample supernatant, $\mathrm{AAba}=$ moles of amino acids determined in the sample supernatant without hydrolysis, and AAtm=the calculated total moles of amino acids in the sample considering the mean molecular weight of the amino acids $(\mathrm{MW}=113)$. 


\section{Results and discussion}

Using the glyoxyl-agarose support, it was possible to achieve high percentages of immobilization for both enzymes, as described in Table 1.

Table 1. Immobilization parameters of papain and trypsin on glyoxyl-agarose support

\begin{tabular}{lcccc}
\hline Enzyme & $\begin{array}{c}\text { Initial protein charge } \\
\text { (per mg support) }\end{array}$ & $\begin{array}{c}\text { Immobilized protein/g } \\
\text { derivative }\end{array}$ & $\begin{array}{c}\text { Immobilization } \\
(\%)\end{array}$ & $\begin{array}{c}\text { Activity recovered** } \\
(\%)\end{array}$ \\
\hline Trypsin & 2.0 & $1.94 \mathrm{mg}$ & $96.7 \%$ & 32.80 \\
Papain & 8.0 & $6.8 \mathrm{mg}$ & $84.9 \%$ & 47.33 \\
\hline
\end{tabular}

*: (Initial protein concentration - final protein concentration in supernatant solution/initial protein concentration $) \times 100$

**: Considering (total activity of derivative/total initial activity of enzyme) $\times 100$

Both enzyme suspensions kept $100 \%$ of the initial activity throughout the exposition time at $\mathrm{pH} 10.2$ buffer during the immobilization procedure. $\mathrm{pH}$ stability of enzymes is an important factor to ensure the success of this procedure, since the immobilization on glyoxyl support is typically performed at high $\mathrm{pH}$, where the reactivity of the terminal amino groups and $\varepsilon$-amino groups of the lysine residues of protein surface may be significant and multipoint interactions can be (MATEO et al., 2006). As previously mentioned, papain is particularly interesting for this immobilization procedure, since it presents a single peptide chain of 211 amino acid residues out of which 11 are lysine residues, but none of these residues is in its active site (YEOM et al., 1999; Roy et al., 2005). After the reduction of derivatives with sodium borohydride, their recovery activities were determined (Table 1). The observed loss of activity is probably related to diffusional problems. Diffusional limitations are usually considered to be a problem that reduces the immobilized enzyme activity when the substrate diffusion inside the support particle is slow. In this case, the enzymes in the core of the derivative particle will not reach the substrate as the surface enzymes would (RoDRIGUES et al., 2013).

The goal of this work was to use immobilized trypsin as a pre-treatment possibility to improve papain performance. Thus, it was necessary to establish the best conditions for the immobilized papain action, where trypsin derivative also presents very good performance. The effects of $\mathrm{pH}$ and temperature on immobilized enzymes have been determined (Figs 1 and 2).

Papain derivative, as well as its free form, had better results when $\mathrm{pH} 7.0$ was applied (Fig. 1A). By increasing the $\mathrm{pH}$ value to 7.5, activities of papain preparations were decreased by about $50 \%$. Trypsin preparations presented optimum value at $\mathrm{pH} 8.5$ (Fig. 1B), but at $\mathrm{pH}$ 7.0 the residual activity was over $75 \%$ to immobilized trypsin. Considering these results, $\mathrm{pH}$ 7.0 was chosen as the suitable environment to maintain both enzymes under the necessary conditions for proteins hydrolysis. When the optimum temperature was established, the activities of papain preparations were increased by increasing the temperature from $37^{\circ} \mathrm{C}$ to $60{ }^{\circ} \mathrm{C}$ (Fig. 2). Above the optimum temperature $\left(60^{\circ} \mathrm{C}\right.$ for both papain samples) a clear reduction in its activities was observed. The immobilized trypsin presented about $90 \%$ of activity at $60{ }^{\circ} \mathrm{C}$ (maximum activity at $65{ }^{\circ} \mathrm{C}$ ). Thus, $60{ }^{\circ} \mathrm{C}$ and $\mathrm{pH} 7.0$ were the choices to meet the best papain conditions, where trypsin derivative also presents very good activity. 
Figure 2 also indicates that the immobilized enzymes were actually more stable than the free enzymes. At $65{ }^{\circ} \mathrm{C}$ more than $80 \%$ of the original activity was lost for papain free enzyme, while the immobilized form presented about $65 \%$ of residual activity. This could be related to a higher stability of the immobilized form via rigidification of the enzyme structure. This effect was more pronounced in the trypsin assay (Fig 2). For free trypsin the optimum temperature was $60{ }^{\circ} \mathrm{C}$, while the immobilized enzyme presented about $90 \%$ of activity at $60{ }^{\circ} \mathrm{C}$ and maximum activity at $65^{\circ} \mathrm{C}$, maintaining a high activity even up to $80{ }^{\circ} \mathrm{C}$ (about $85 \%)$. At this temperature the free trypsin was almost inactive.
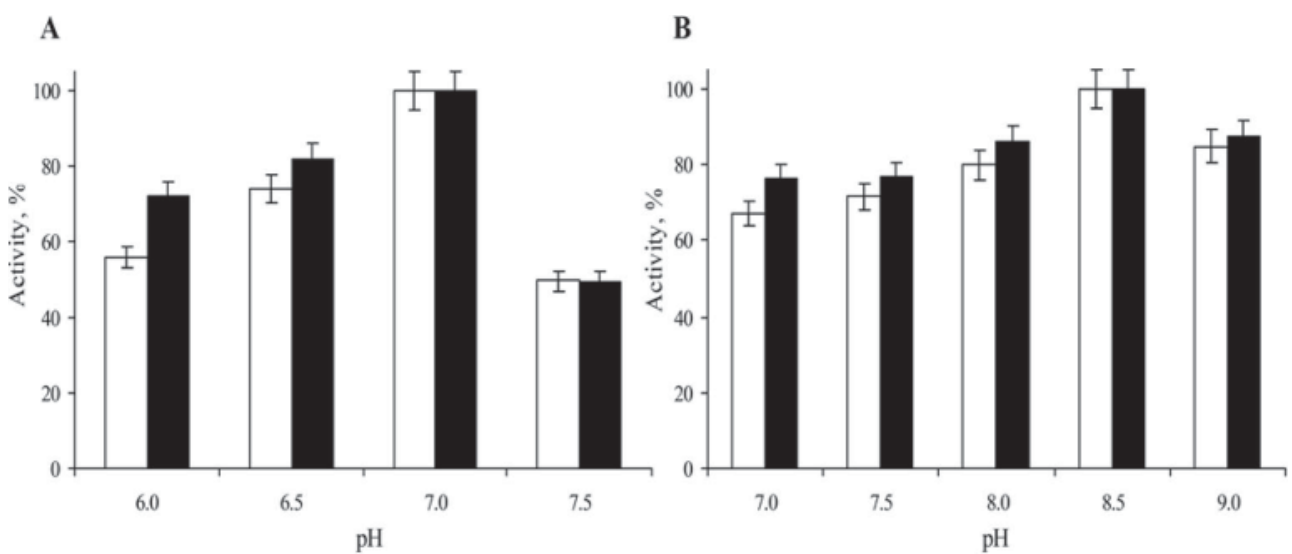

Fig. 1. Effect of $\mathrm{pH}$ on free and immobilized papain (A) and trypsin (B) activity, measured at $50{ }^{\circ} \mathrm{C}$, using BAPNA substrate, as detailed in Methods. Error bars show standard deviation. Results are means of triplicate determinations. $\square$ : free; $\square$ : immobilized

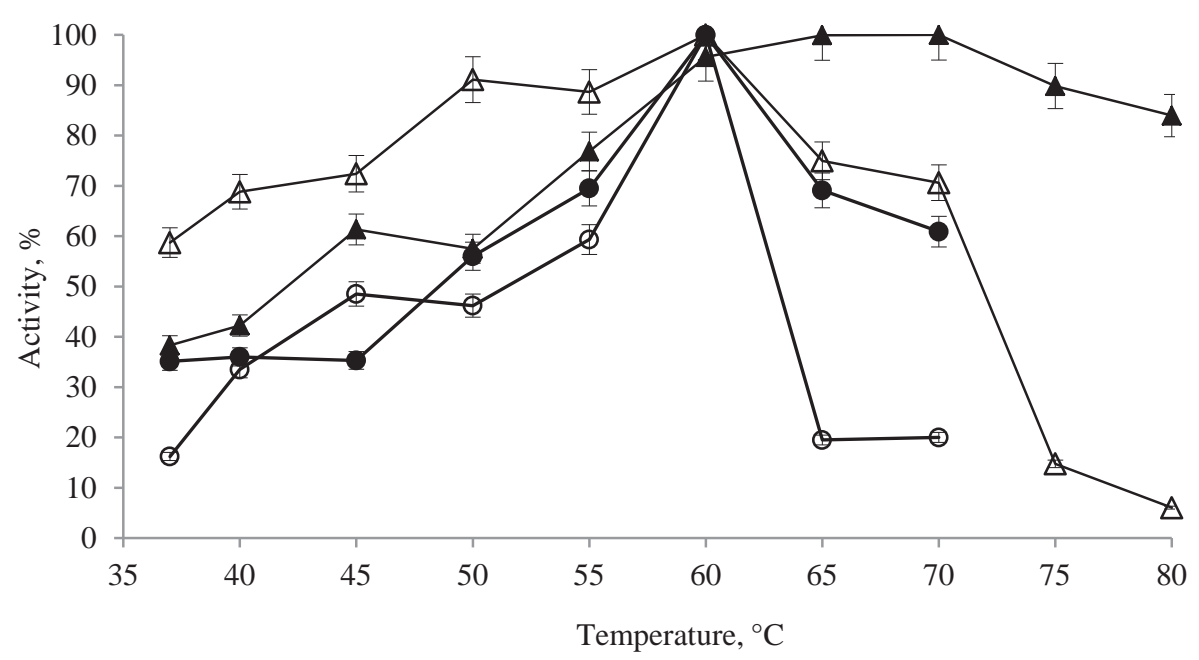

Fig. 2. Effect of temperature on activity of free and immobilized papain $(\bigcirc, \boldsymbol{O})$ and trypsin $(\triangle, \boldsymbol{\Delta})$, measured at pH 7.0, using BAPNA substrate, as detailed in Methods. Error bars show standard deviation. Results are means of triplicate determinations. 
Casein and $\beta$-lactoglobulin were able to be degraded when subjected to both papain preparations (Fig. 3A and B). The slower hydrolysis rate using immobilized trypsin was expected, and appears to be more related to diffusional problems of substrates, as described previously, than environmental conditions.

A

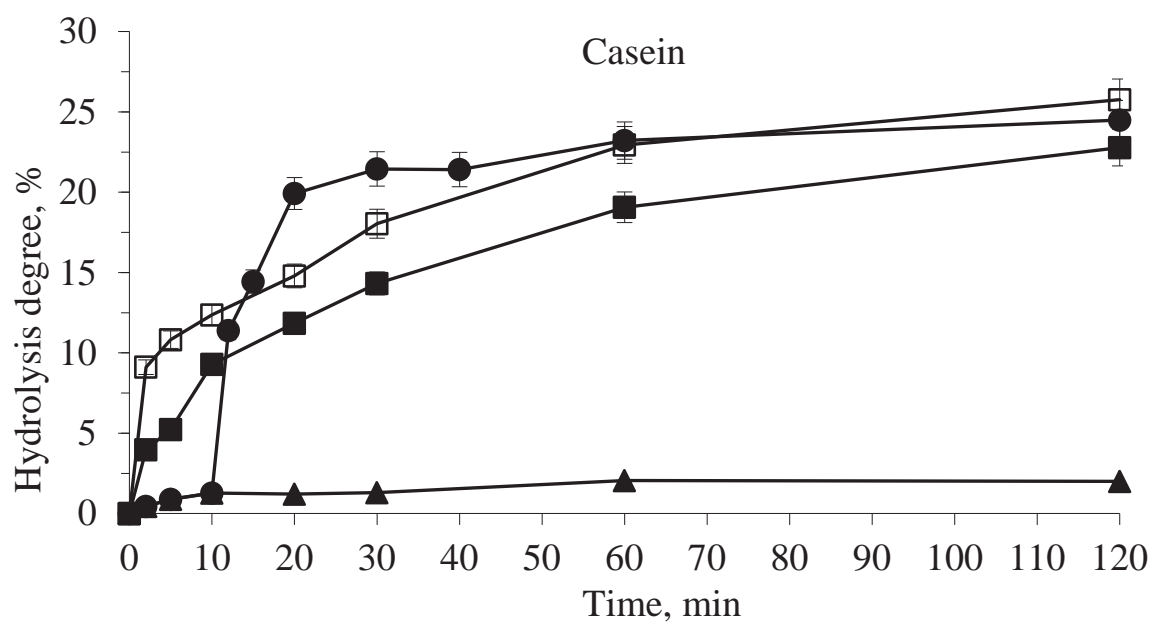

B

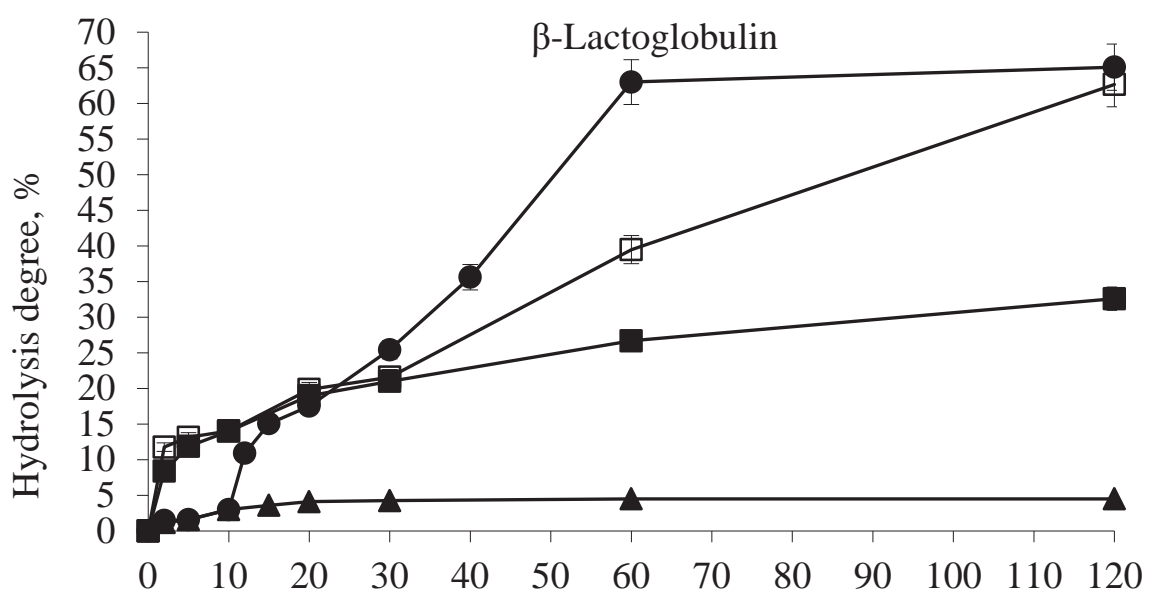

Time, $\min$

Fig. 3. Hydrolysis patterns for casein (A) and $\beta$-lactoglobulin (B) by free papain ( $\square$ ), by immobilized papain $(\mathbf{\square})$, immobilized trypsin $(\mathbf{\Lambda})$, and by immobilized trypsin (10 $\mathrm{min})$ combined with immobilized papain $(\mathbf{O})$, at $60^{\circ} \mathrm{C}$ and $\mathrm{pH} 7.0$, as detailed in Methods. Error bars show standard deviation. Results are means of triplicate determinations

As it is known, $K_{\mathrm{m}}$ value can increase due to restricted diffusion of substrate or the high structural rigidity of immobilized enzyme (Rodrigues et al., 2013; TAVANo et al., 2013). HOMAEI and co-workers (2010) observed a slight increase in $K_{\mathrm{m}}$ value when papain was 
immobilized in cyanogen bromide activated Sepharose. In immobilized protease applications, the macromolecular nature of the substrates may be a problem (RoDRIGUes et al., 2013). This can be particularly important at the beginning of the proteins hydrolysis process, when whole proteins are present and the large size of their chains could restrict the access to the inside of the derivative. In the course of the reaction, surface immobilized enzymes begin to release smaller fragments, which make the substrate solution more susceptible to derivative hydrolysis, progressively overcoming the support barrier. The larger and more complex the protein chain is, the bigger difficulties in starting hydrolysis can appear. This can be clearly noted about casein profile, and especially in the $\beta$-lactoglobulin hydrolysis profile (both complex protein chains), when immobilized papain was used on comparison to the free enzyme (Fig. 3A and B).

As a means of speeding up the reaction, the purpose was the pre-hydrolysis of the milk substrates with immobilized trypsin before using papain immobilized for digestion. Casein and $\beta$-lactoglobulin hydrolysis profile using immobilized trypsin (Fig. 3A and B) indicated that 10 min of digestion process was enough for digestion by immobilized trypsin to reach the highest possible hydrolysis degree, and, on the other hand, to avoid a very time consuming step on the protocol. This procedure was enough to accelerate the papain derivative performance. In fact, when the pre-hydrolysis was used, the immobilized papain was able to achieve the maximum degree of hydrolysis (considering the level reached at the end of the free enzyme process) in shorter times. As shown in Figure 3, for pre-hydrolysate casein, the immobilized papain reached $19.9 \%$ of hydrolysis within the first 10 min of contact with this digest, which means after a total 20 min hydrolysis, and reaching $23.22 \%$ at 60 min total reaction (including the ten min pre-digestion). The highest casein hydrolysis degree was $24.49 \%$. As for $\beta$-lactoglobulin (Fig. 3B), immobilized papain was capable of achieving maximum levels of hydrolysis after only 60 min of reaction $(63.0 \%)$, where the free enzyme only achieved about $60 \%$ of its maximum activity (39.47\%). These results suggest that in fact the macromolecular characteristic of substrates hinders the access to immobilized enzymes, since the same substrate, when offered as smaller fragments, facilitated the course of hydrolysis. Given these observations, immobilized trypsin could be applicable for this prehydrolysis step, partly due to its specificity, which cleaves Lys and Arg amino acid residues. The large generated fragments may well contain further sites for hydrolysis by surface or internal immobilized papain, which catalyses hydrolysis of peptide bonds of basic amino acids such as leucine or glycine (GANAPATHY et al., 2001).

These observations demonstrate that conducting hydrolysis with the use of immobilized enzymes can be highly feasible. While there may be problems, such as diffusional difficulties, and consequent reduction in the speed of reaction, these can be circumvented. Beside that, we have to consider the ease of handling of the catalyst and the possibility of interrupting the reaction, which may allow for greater control of the process and products generated.

\section{Conclusions}

Pre-hydrolysis with trypsin appears to work well as a pre-treatment method for the action of papain. The pre-hydrolysis reduced the time needed for immobilized papain to reach the hydrolysis levels of its free form when $\beta$-lactoglobulin and casein were tested. Protein hydrolysis using immobilized proteases can have disadvantages when compared to the free enzyme, such as reducing the release rate of the peptides. But if this problem is mainly 
caused by the diffusion of macromolecular substrate, as suggested in this study, it can be circumvented by using a pre-hydrolysed substrate.

We would like to thank FAPEMIG-Fundação de Amparo à Pesquisa do Estado de Minas Gerais-Brazil for the financial support ( $\mathrm{N}^{\circ}$. CAG - APQ-00799-09) and fellowship for Tassia B Pessato (BIC/FAPEMIG). We feel grateful to Profa. Dra. Roseli A. da Silva Gomes for making available the resources of the Biochemical and Biophysical Laboratory/UFTM and Ney Pereira for his help during the linguistic revision.

\section{References}

BRADFORD, M.M. (1976): A rapid and sensitive method for the quantification of microgram quantities of protein utilizing the principle of protein-dye binding. Anal. Biochem., 72, 248-254.

Church, F.C.C., Swaisgood, H.E., Porter, D.H. \& Catignani, G.L. (1983): Spectrophotometric assay using $o$-phthaldialdehyde for determination of proteolysis in milk and isolated milk proteins. J. Dairy Sci., 66, $1219-1227$.

Clemente, A. (2000): Enzymatic protein hydrolysates in human nutrition. Trends Food Sci. Tech., 11, 254-262.

Dupont, D., Mandalari, G., Molle, D., Jardin, J., Leonil, J., Faulks, R.M., Wickham, M.S.J., Mills, E.N.C. \& MACKIE, A.R. (2010): Comparative resistance of food proteins to adult and infant in vitro digestion models. Mol. Nutr. Food Res., 54, 767-780.

El-Agamy, E.I. (2007): The challenge of cow milk protein allergy. Small Ruminant Res., 68, 64-72.

Ganapathy, R., Manolache, S., Sarmadi, M. \& Denes, F. (2001): Immobilization of papain on cold-plasma functionalized polyethylene and glass surfaces. J. Biomater. Sci. Polym. E., 12, 1027-1049.

GuIsÁn, J.M. (1988): Aldehyde-agarose gels as activated supports for immobilization stabilization of enzymes. Enzyme Microb. Tech., 10, 375-382.

Homaei, A.A., Sajedi, R.H., Sariri, R., Seyfzadeh, S. \& Stevanato, R. (2010): Cysteine enhances activity and stability of immobilized papain. Amino Acids, 38, 937-942.

KaKade, M.L., Rackis, J.J., McGhee, J.E. \& Puski, G. (1974): Determination of trypsin inhibitor activity of soy products: A collaborative analysis of an improved procedure. Cereal Chem., 51, 376-382.

Kleber, N., Krause, I., Algner, S. \& HinRichs, J. (2004): The antigenic response of $\beta$-lactoglobulin is modulated by thermally induced aggregation. Eur. Food Res. Technol., 219, 105-110.

Mateo, C., Palomo, J.M., Fuentes, M., Betancor, L., Grazu, V., López-Gallego, F., Pessela, B.C.C., Hidalgo, A., Fernández-Lorente, G., Fernández-Lafuente, R. \& Guisán, J.M. (2006): Glyoxyl agarose: A fully inert and hydrophilic support for immobilization and high stabilization of proteins. Enzyme Microb. Tech.., 39, 274-280.

Otte, J., Shalaby, S.M., Zakora, M., Pripp, A.H. \& El-Shabrawy, S.A. (2007): Angiotensin-converting enzyme inhibitory activity of milk protein hydrolysates: Effect of substrate, enzyme and time of hydrolysis. Int. Dairy J., $17,488-503$.

Rodrigues, R.C., Ortiz, C., Berenguer-Murcia, A., Torres, R. \& Fernandez-Lafuente, R. (2013): Modifying enzyme activity and selectivity by immobilization. Chem. Soc. Rev., 42, 6290-6307.

Roy, J.J., Sumi, S., SAngeetha, K. \& Abraham, T.E. (2005): Chemical modification and immobilization of papain. J. Chem. Technol. Biot., 80, 184-188.

SAmpson, H.A. (1999): Food allergy. Part 1: Immunopathogenesis and clinical disorders. J. Allergy Clin. Immun., 103, 717-728.

Silva, S.V. \& Malcata, F.X. (2005): Caseins as source of bioactive peptides. Int. Dairy J., 15, 1-15.

Tavano, O.L. (2013): Protein hydrolysis using proteases: An important tool for food biotechnology. J. Mol. Catal. B-Enzym., 90, 1-11.

Tavano, O.L., Fernandez-Lafuente, R., Goulart, A.J. \& Monti, R. (2013): Optimization of the immobilization of sweet potato amylase using glutaraldehyde-agarose support. Characterization of the immobilized enzyme. Process Biochem., 48, 1054-1058.

Ulbrich-Hofmann, R., Arnold, U. \& Mansfeld, J. (1999): The concept of the unfolding region for approaching the mechanisms of enzyme stabilization. J. Mol. Catal. B-Enzym., 7, 125-131.

Yeom, H.W., Zhang, Q.H. \& DunNe, C.P. (1999): Inactivation of papain by pulsed electric fields in a continuous system. Food Chem., 67, 53-59.

Yust, M.M., Pedroche, J., Millán-Linares, M.C., Alcaide-Hidalgo, J.M. \& Millán, F. (2010): Improvement of functional properties of chickpea proteins by hydrolysis with immobilised alcalase. Food Chem., 122, 12121217. 